\title{
Energy requirement for the sowing of wheat after the in-situ management of paddy residues
}

\author{
Parveen, Ajaib Singh and Ritu Dogra
}

Received : 18.11.2019; Revised : 21.01.2020; Accepted : 06.02.2020

See end of the Paper for authors' affiliation Correspondence to :

Parveen

Department of Farm Machinery and Power Engineering, Punjab Agricultural University, Ludhiana (Punjab) India Email: parveenfmpe@gmail. com
- ABSTRACT : The present study assessed the energy requirement for the harvesting of paddy with combine harvesting with/without Super Straw Management System and wheat sowing with different farm machinery having straw retention and straw incorporated in the fields. The straw retention treatments i.e. $\mathrm{T}_{1}$ and $\mathrm{T}_{2}$ whereas straw incorporation treatments i.e. $\mathrm{T}_{3}$ and $\mathrm{T}_{4}$ were taken in the study. The total energy consumption was maximum for treatment $\mathrm{T}_{4}(5529.92 \mathrm{MJ} / \mathrm{ha})$, followed by treatment $\mathrm{T}_{3}(5487.47 \mathrm{MJ} / \mathrm{ha})$, followed by treatment $\mathrm{T}_{2}(3485.15 \mathrm{MJ} / \mathrm{ha})$ and treatment $\mathrm{T}_{1}(2539.40$ $\mathrm{MJ} / \mathrm{ha})$. The least human energy consumption (22.01 MJ/ha), diesel energy (551.95 MJ/ha) and tractor and machinery energy $(551.95 \mathrm{MJ} / \mathrm{ha})$ was observed for treatment $\mathrm{T}_{1}$, while the maximum human energy, diesel energy, and tractor and machinery energy was observed in treatment $\mathrm{T}_{4}$ (52.17 MJ/ha), $\mathrm{T}_{3}\left(3442.63\right.$ and $\mathrm{T}_{4}(644.89 \mathrm{MJ} / \mathrm{ha})$. The electrical energy $(1401.78 \mathrm{MJ} / \mathrm{ha})$ and submersible pump energy (13.68 MJ/ha) was observed in treatment $\mathrm{T}_{3}$ and $\mathrm{T}_{4}$, respectively. The residue retention practice of wheat sowing with Happy Seeder after paddy harvesting with combine harvester having Super Straw Management System is the efficient energy input to manage the paddy residue.

- KEY WORDS : Energy, Straw management, Wheat sowing, Straw retention, Incorporation

- HOW TO CITE THIS PAPER : Parveen, Singh, Ajaib and Dogra, Ritu (2020). Energy requirement for the sowing of wheat after the in-situ management of paddy residues. Internat. J. Agric. Engg., 13(1) : 10-18, DOI: 10.15740/HAS/IJAE/13.1/10-18. Copyright@2020: Hind Agri-Horticultural Society. 